\title{
浅谈初中语文教学中的情感教育
}

\author{
刘红叶 \\ 湖南省长沙市雅礼洋湖实验中学
}

DOI:10.32629/jief.v2i5.1417

[摘 要] 在新课程改革背景下, 初中语文学科要想达到更好的教育效果, 为素质教育目标的实现带来支持, 就必须发挥出语文知识的特征, 提升课堂教学效果。情感教育策略作为新课程改革当中所推荐的教学模式, 其因为能够抓住语文学科的内涵, 并在教学过程中能够带给学生 良好的学习体验，而受到了初中语文教师的教学青睐。为了更好的发挥出情感教育模式在初中语文教学中的作用，对其予以分析很有必要。 本文将主要结合语文教学的多个方面进行分析，提出引用情感教育的有效策略。

[关键词] 初中语文; 情感教育; 课堂教学; 有效策略

中图分类号: G633.3 文献标识码: A

语文是一门人文性较强的学科。情感教育对于学生的影响十分长远, 在教学中渗透情感教育有利于学生的未来发展和学习。尤其在语文学科 中, 开展情感教育能够起到相互相成, 事半功倍的良好效果。

\section{1 初中语文教学的情感教学现状分析}

在初中语文教学中, 经常会出现学生的理解能力低和对语文提不起 兴趣的现状, 主要原因就是初中语文教师在教学中只是在灌输知识, 不 注重学生的情感教育, 使学生对语文感到厌倦。就初中学生而言, 他们 经过小学语文教学, 本就有自己对语文的观点和看法, 对于传统的教学 方法也产生了厌倦感。对初中语文教师而言, 老师太过关注学生成绩而 不注重学生的情感思维, 致使学生对语文的兴趣被削弱。情感教学在初 中语文教学中的有效应用, 不仅能提高学生对语文的积极性, 而且还可 以找到解决初中语文教学中情感缺失的途径。

\section{2 情感教学在初中语文教学中应用的积极性}

在初中语文教学上, 大多老师只注重学生的学习成绩, 而忽略了学 生在语文学习过程中的情感教学。情感教学在初中语文教学上的有效应 用, 不仅能够使学生对语文产生积极性, 还能提高语文课堂的学习质量, 在语文教学中, 如果丢失了情感, 那这就像人类丢失情感 “行尸走肉” 一般, 而通过对初中语文教学开展情感教学, 找到了解决初中语文教学 中情感缺失的一个重要途径。

\section{3 情感教学在初中语文教学中应用的相关措施}

3.1 挖掘文章背景, 引发学生与作者之间的共鸣

语文是一门艺术性极强的学科, 学生对文章写作背景的了解程度对 理解整篇文章内容有着非常重要的作用, 因此教师要抓住这一点, 以文 章的背景为依据, 带领学生共同探索作者的内心世界, 使学生与作者产 生情感共鸣。挖掘文章背景应当从两个方面做起, 第一是时代背景, 时 代会造就文人, 也会影响文人的写作特点, 时代既是作者所处的环境, 同时也为作者提供写作的素材。因此, 挖掘文章的时代背景对理解作者 的写作目的和文章深层含义来说至关重要。第二是作者生平, 许多作者 的文章是对他们生平经历的复述和经验总结, 其中包含的许多至理名言 也是他们经验的副产品, 因此了解作者的生平对理解文章内容和情感来 说也非常重要。学生只有了解了一篇文章的时代背景和作者的生平经历, 才能对这篇文章的理解更加深刻, 才能超越文字和时代的限制, 与作者 的情感产生共鸣。

3.2 有感情地朗读文章, 使学生体验文章的情感

有感情地朗读课文是许多教材文章的课后习题之一, 虽然它一直存 在于初中语文教学的舞台上, 但许多学生对它却并不重视, 还经常觉得 这是在做无用功。事实上, 学生有感情地朗读课文不仅能够加深自身对
文章内容的印象, 还能在朗读过程中积累文章的好词好句, 将其作为写 作的素材。此外, 教师作为受过专业训练的教育者, 在有感情地朗读课 文时, 又会产生不一样的效果, 学生可以根据教师在朗读过程中的读音 轻重或者停顿, 体会文章的情感起伏, 从而将书本上的文字转化为三维 的情感体验。在组织有感情地朗读课文的教学过程中, 教师应当注意两 个方面: 一是投入感情; 二是带领学生诵读。没有投入感情的朗读和复 读机没有什么差别, 既不能分享文章的情感变化, 也不能为学生提供良 好的情感体验, 因此在朗读过程中, 教师要合理地控制感情, 使每一句 的情感都恰到好处。

3.3 注重师生情感建设, 创造良好教学环境

要使情景教学更好的运用到语文教学中, 教师就应该注重师生的情 感建设, 营造出良好的教学环境。在我国的传统教学中, 老师占领着主 导地位, 而学生只是一味接受老师灌输的知识, 使学生的主体地位并没 有的到很好的发挥。良好的教学环境是指学生与教师之间的平等沟通和 互动。那么, 要怎样注重师生的情感建设呢? 就比如说, 在期末复习时, 老师可以组织班上开展古诗文默写的知识竞赛, 教师是裁判, 学生是参 赛选手, 通过这样的复习方法既能加強学生与老师在学习上的交流, 又 能使学生了解到自身在古诗文上的复习上的不足。像这种方法, 教师把 将学生的主体地位凸显出来, 与学生在学习上交流, 成为良师益友, 通 过培养教师与学生的情感, 使学生在和谐的教学环境中学习, 课堂气氛 融洽, 创造出良好的教学环境, 要使教学符合这样的教学环境, 就需要 学生的情感可以在语文课堂上有效实施。由此看来, 注重师生情感建设, 是一个较好的方法之一。

\section{4 结束语}

总的来说, 情感教学在初中语文教学中的有效应用是对语文传统教 学的一次创新性改革, 它让学生更加的容易接受这一方法, 并且激励学 生对语文这一学科产生兴趣。而要使情感教学的有效应用, 还需要语文 教师去积极探索。

\section{[参考文献]}

[1]董彦.论新课改下农村初中语文有效教学策略 [J]. 新课 程,2020(37):1.

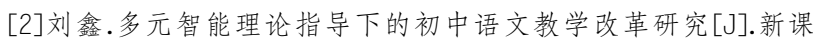
程,2020(37):25.

[3]柴秀巧.初中语文阅读教学中展示环节的优化探究 [J]. 新课 程,2020(37):26. 